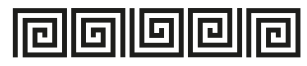

PHILOLOGIA CLASSICA
DE PHILOLOGIS ET

PHILOLOGIA
回|⿴囗口回回回

VOL. 15. FASC. 1. 2020

UDC 811.124

\title{
"Opus trium deorum": A Note on the Origin of Annotationes ex Scriptis Karoli Episcopi Arosiensis
}

\author{
Arsenij A. Vetushko-Kalevich \\ Lunds Universitet, Språk- och litteraturcentrum, \\ Helgonabacken 12, Box 201, 22100 Lund, Sverige; \\ arsenii.vetushko-kalevich@klass.lu.se
}

For citation: Arsenij A. Vetushko-Kalevich. "Opus trium deorum": A Note on the Origin of Annotationes ex Scriptis Karoli Episcopi Arosiensis. Philologia Classica 2020, 15 (1), 154-161.

https://doi.org/10.21638/spbu20.2020.111

One of the most famous academic conflicts in $17^{\text {th }}$ century Sweden was a quarrel between Johannes Schefferus and Olof Verelius in the 1670s concerning the original position of the city of Uppsala and its heathen temple, mentioned by Adam of Bremen. After a series of publications with mutual attacks Verelius published in 1678 a document entitled Annotationes ex scriptis Karoli Episcopi Arosiensis excerptae, pretending to go back to a lost medieval source. Schefferus answered with an analysis of the document, proving it to be a forgery. Despite Schefferus' brilliant and convincing philological investigation, Annotationes have often been regarded as a genuine medieval source, especially after the publication of a monograph by the Swedish historian Kjell Kumlien in 1967. Recently, several historical and philological surveys have opposed Kumlien's views, providing additional arguments in favour of Schefferus' claims. This article aims at adding one more: an odd juncture in the text of Annotationes - 'opus trium deorum' that is to be understood as 'a temple of three gods' - can be explained by an ambition of the forger to imitate Adam of Bremen, whose text belonged to the central ones in the controversy.

Keywords: Johannes Schefferus, Olof Verelius, literary forgery, genitivus subiectivus, Gamla Upsala.

The invitation of famous scholars from the continent was an important contribution to the rise of Swedish education and scholarship in the $17^{\text {th }}$ century. However, most of the foreign guests stayed there for just a few months or years, earning their renown outside Sweden. There are just two prominent exceptions, namely the historian Johannes Locceni-

(C) St. Petersburg State University, 2020 
us (1598-1677) who, being born in Holstein, was active in Sweden for half a century, and his son-in-law, Johannes Schefferus (1621-1679), from Strasburg. The final episode in the career of the latter is what I am going to deal with in this article.

Schefferus got an impressive education in his home town, and upon entering the university, was sheltered by the prominent historian Johann Boeckler. Still, despite some early academic merits (in particular, a monograph on ancient shipbuilding), he did not manage to obtain a position at the university (Schefferus 1915, 13-17). In 1648, another scholar from Strasburg, Johannes Freinshemius, who was employed in Sweden as professor Skytteanus at Uppsala University, became Queen Christina's librarian, with his position vacant. Boeckler, with whom Freinshemius got in touch, recommended Schefferus for the professorship. So he undertook a long and fascinating journey to the North and visited several European centres of learning on his way, in particular Leiden and Sorø (Schefferus 1915, 17-18). After arriving in Uppsala, he stayed in Sweden for the rest of his life.

Schefferus is regarded to be the first Swedish classical philologist (although he founded no "school" around him). The position as professor Skytteanus implied teaching political eloquence. In the Early modern period this task was mainly connected with commenting on relevant classical authors. From Schefferus' autobiography we learn that during his first year in Uppsala he lectured on Pliny the Younger, next year on Livy, then on Pacatus and so on (Schefferus 1915, 21-22). At the same time he was actively working on editions of the classics; in particular, worth mentioning are his editio princeps of Pseudo-Mauricius (1664) and the edition of Trimalchio's Feast (1665) provided with an article in support of its authenticity.

Schefferus was also interested in history and culture of his new home country. Perhaps, his most well-known book is Lapponia (1673), soon after the publication translated from Latin into several European languages. Memorabilia Sueticae gentis exempla (1671), modelled after Valerius Maximus, is an enjoyable reading until now. Svecia literata, published posthumously in 1680, was the first full-scale bibliographical reference work in Sweden and has not yet completely lost its value.

Unfortunately, the interest in Swedish history together with a sober scholarly attitude to it made inevitable a confrontation with academic circles around Olof Rudbeck. This latter was in process of preparing for publication a monumental treatise Atlantica, where he argued that Swedish civilization must have been several thousand years old and identified it with Plato's Atlantis. The conflict with Rudbeck's close ally Olof Verelius (1618-1681) eventually gloomed Schefferus' last years.

It was Schefferus' historical-topographical work Upsalia (1666) that triggered the quarrel. Verelius, who is particularly known as a pioneer of scholarship on Old Norse literature, exposed some of Schefferus' claims to harsh criticism in a commentary to Hervarar saga, published in 1672. Verelius was especially unhappy with identifying the oldest settlement in Uppsala with the modern position of the city (formerly "Östra Aros"), not with the village of Gamla Upsala (i. e. "old Uppsala") several kilometers to the North. Schefferus considered the name of Gamla Upsala to have emerged as late as in the $13^{\text {th }}$ century and not to be paid credit to. Rudbeck, on the other hand, with his fanciful archeological methods was just on the way to find the traces of the heathen temple, mentioned by Adam of Bremen, in the fundament of Gamla Upsala church, and any doubts in this historical link, utterly important for the whole Rudbeckian theory, were to be confronted bitterly. 
(It should be noted that in the matter of fact Verelius was ultimately right. Although it is still highly questionable whether the heathen temple was situated precisely on the spot of Gamla Upsala church and, moreover, whether it existed at all, it is now commonly accepted in historical scholarship that Gamla Upsala was the original settlement, considerably older than what now is Uppsala. Schefferus relied on his medieval sources too much.)

Several polemical writings were printed in the discussion between Schefferus and Verelius in the 1670s. Finally, in the spring of 1677, Magnus Gabriel De la Gardie, the Chancellor of the Realm, issued an interdict against further replies in the quarrel, an interdict that was rather favourable for Schefferus, who was the last to answer. Nevertheless, just a year later a remarkable document that could be decisive in the discussion fell into the hands of Verelius - according to his own testimony, he received it from Rudbeck. It was not forbidden to publish historical sources, and the document was printed. Let us quote it in full:

Annotationes ex scriptis Karoli Episcopi Arosiensis excerptae. Ex MS. o membraneo vetusto nunc primum in lucem prolatae.

MCXXX. $\quad$ Nicolaus Vlpher Episcopus Vpsalensis.

MCXXXIIX. Suerchr I jecit fundamenta templi Chatedralis Vpsalae, et cum opere vetusto III. Deorum paganico, ab Yggemundo igne purificato et sanctificato conjunxit.

MCXLII. Sveno Kolle Episcopus Vpsalensis.

MCL. Beatus Ericus templum Cathedrale perfecit, et Hinricus Episcopus illud B.V. Mariae $\quad-\quad-$ - Augusti, die asscensionis consecravit.

MCLIII. $\quad$ B. Ericus in medio templi B. V. Mariae sepultus.

MCLV. Stephanus Monachus Episcopus Vpsalensis, Anno MCLXIV. ArchiEpiscopus creatus.

MCLXXXVIII. Iohannes Archi-Episcopus Vpsalenssis.

MCLXXXIX. Petrus Archi-Episcopus Vpsalensis.

MCXCVIII. Olafr Archi-Episcopus Vpsalensis.

MCCII. Vallerius Archi-Episcopus Vpsalensis.

MCCX. Templum ad Estraaroos et Vllrakr exstructum a Sverchero II.SS. Trinitati consecratum.

MCCXIX. Olafr Basatamur Archi-Episcopus Vpsalensis.

MCCXXXVII. Iarl Archi-Episcopus Vpsalensis.

MCCLVIII. Impetratum a Papa Alexandro pro translatione Ecclesiae Vpsalensis ad Estraaroos.

MCCLX. Sub Baldemaro jacta sunt fundamenta templi Cathedralis Estraaroos, et ad tectum eductum.

MCCLXI. Laurentius Archi-Episcopus Vpsalensis.

MCCLXXI. Nos implevimus mandatum S. Papae pro translatione Ecclesiae Vpsalensis ad Estraaroos. 
The edition was provided with an introduction (containing renewed attacks against Schefferus) and a short commentary. Some days afterwards a second edition appeared, this time without an introduction, but with an affirmation of the print's exact correspondence to the manuscript, signed by professors Andreas Norcopensis and Johan Gartman (both were allies of Rudbeck as well) and a report of some German soldiers who, led by Rudbeck, had inspected the basis of Gamla Upsala church and claimed to have seen clear traces of the former heathen temple.

Just weeks later Schefferus published his critical review of the Annotationes, entitled De excerptis annotationibus ex scriptis Caroli episc. Arosiensis per adversarios expressum judicium. This analysis is a true masterpiece of Early Modern textual criticism, quite unique for Sweden in particular.

In the preface Schefferus laments the need to take part in a lengthy emotional quarrel despite his multiple merits for Swedish scholarship - and to do it now, when he is aged and sickly. Still, both Verelius' preface to the Annotationes and their very contents make it necessary to continue the discussion, albeit "nullo scribendi pruritu". He promises to confine himself to the analysis of the text, putting aside his personal wounds (Schefferus $1678,7)$.

Schefferus' arguments against the authenticity of Annotationes can be divided into several groups.

\section{(1) The circumstances of the publication}

The document emerged with the help of Verelius' own sympathizers and appeared at the moment when it was most needed. Its contents make one think that the medieval bishop or at any rate the author of the excerpts had foreknown the discussion of Schefferus and Verelius and thus constructed his very short "chronicle" of the events connected with the foundation and the transfer of the churches in Uppsala, without forgetting to mention the heathen temple (Schefferus 1678, 11-12, 18).

Nobody had had any notion of bishop Charles' writings before, although it is hardly believable that Rudbeck's father Johannes Rudbeckius, a bishop of Västerås himself, could have missed such an important historical source preserved in his own library. Finally, the nation-wide ordinance to look for medieval historical documents and to send them to the Collegium Antiquitatum in Stockholm had been issued a decade before, in 1667 - but Rudbeck made no haste to find the manuscript, and Verelius chose for some reason to publish it himself instead of submitting it to the expert evaluation (Schefferus 1678, 12-14).

\section{(2) Literary details}

The plural 'scriptis' in the title looks strange. Firstly, the contents of the Annotationes rather suggest that they had been based on one single work. Secondly, had bishop Charles been such a prolific author as to ascribe to him a series of works, he would hardly have been as completely forgotten as he was (Schefferus 1678, 15-16). And isn't that awkward, the bishop of Västerås writing exclusively about Uppsala? Verelius himself is aware of this difficulty in his commentary and suggests that the one who made excerpts was from Uppsala - but why, then, the existence of the writings had been ignored in Uppsala just like elsewhere for centuries? 
Besides, it is difficult to understand why a certain person decided to make excerpts of a chronicle, which, so far one can judge from a comparison with other works from the period, must itself have been utterly concise (Schefferus 1678, 14). On the other hand, a series of exact dates raises suspicions: "Nimirum rem noverunt omnes receptam apud veteres, consignare breviter vocabula hominum et res gestas, annos atque tempus silentio praeterire. Quod nisi hospes in Antiquitatibus Svecorum negare nemo poterit" (Schefferus 1678,22 ).

The last record in the Annotationes is noteworthy, as bishop Charles turns out to quote himself, almost verbatim repeating a sentence from a real medieval letter (Schefferus 1678, 34), published by Schefferus several years before (Schefferus 1673, 28).

\section{(3) Chronological details}

The dates given in the document diverge from or conflict with the commonly accepted ones on several occasions. The crassest example is the burial of Saint Eric in 1153, who actually died in 1160 (Schefferus 1678, 29).

\section{(4) Lexical details}

In the record under the year 1150 the Assumption of the Virgin Mary into Heaven is called ascensio, whereas the correct catholic term is assumptio: to ascend by his own force was a privilege of Christ. A medieval bishop could not fail to know that. The mistake is perhaps due to the Swedish language using the same word ('himmelsfärd') for both phenomena. Another strange detail is the reference to the heathen temple, which is both pleonastic ("Quid enim si paganicum, necesse fuit addere vetustum?") and lexically dubious (Schefferus 1678, 23-24; see the discussion below).

\section{(5) Paleographical details}

Schefferus informs us that he had got the opportunity to look at the manuscript, ${ }^{1}$ although "brevissimo temporis spatio". It only confirmed his doubts (Schefferus 1678, 41). The manuscript is a sheet of approximately duodecimo size, torn apart from a Swedish-language manuscript of medical and botanical contents. The handwriting has not much in common with medieval Latin manuscripts and rather resembles Icelandic manuscripts donated to the Collegium Antiquitatum by M. G. De la Gardie (Schefferus 1678, 42). The ink is not pale enough to be several centuries old, but on the other hand it is diluted with water - "ad praeferendam vetustatem". The letter p occurs in the manuscript, which is unthinkable for a medieval Latin text, and the form of the letter F imitates... the Gothic Codex argenteus, donated by De la Gardie to the Uppsala university in the 1660s. Finally, to fill a lacuna with a dash, as is done in the manuscript, is a modern habit, whereas the medieval scribes either do not signalize the lacuna at all or leave a space on its place (Schefferus 1678, 43).

1 The manuscript perished in the fire of 1702 , but an accurate copy of it, probably reproducing its slightest graphical traits, is preserved. For a photo of this copy, see Kumlien 1967, 9. 
It should be admitted that not every argument by Schefferus taken alone is decisive, but the overall conclusion looks quite safe: Annotationes are a forgery, and of a poor quality. Still, its further history in the scholarship is remarkable.

Verelius himself, accused in this way of publishing a forged document and even questioned on this matter by the university consistory, does not seem to have answered any of the objections in particular, only complaining about the calumny he had been exposed to. Later on (beginning with Klas Örnhiälm's Historia Sveonum Gothorumque ecclesiastica from 1689) voices has been raised both in favour and against the authenticity of the Annotationes (Kumlien 1967, 6-8).

At the end of the $19^{\text {th }}$ century Claes Annerstedt, a famous specialist in the history of the Uppsala university, published an article on the quarrel between Schefferus and Verelius (Annerstedt 1891), and devoted considerable attention to the discussion of the Annotationes. Completely agreeing with Schefferus' arguments, Annerstedt adds some more, pointing at the inconsequent spelling of the proper names and at the dilettantish usage of medieval-styled abbreviations in the manuscript (Annerstedt 1891, 144-145).

Nevertheless, in 1967 Kjell Kumlien published a monograph entitled Biskop Karl av Västerås och Uppsala ärkesätes flyttning, where he endorsed the authenticity of the Annotationes. Kumlien admits that the quality of the document does not allow to regard it as medieval (Kumlien 1967, 59), but does not consider it necessary to suppose a deliberate forgery. Kumlien suggests that bishop Charles indeed wrote some historical account about the church in Uppsala and this account fell into oblivion, but an unknown person in the $16^{\text {th }}$ or the $17^{\text {th }}$ century produced some excerpts of this account. It was these excerpts (of very poor quality) that fell into Rudbeck's and later Verelius' hands in the late 1670s. Kumlien blames Schefferus for his methodological near-sightedness, whereas Verelius and his later supporter Eric Benzelius are praised for a "more comparative" approach (Kumlien 1967, 65-66).

Kumlien's hypothesis, presupposing a series of hardly plausible assumptions and principally denying a difference between "poor quality" and conscious stylization (see in particular Kumlien 1967, 44), is rather suitable as a plan for a postmodern novel than as a serious contribution to the textual history of Annotationes. Nevertheless, its conclusions were enthusiastically adopted by large parts of Swedish archeological community, bishop Charles was brought back to life and has become a frequent point of reference in scholarly literature (see a long list in Sävborg 2017, $66 \mathrm{nn} .10-12$ ), penetrating as far as into Reallexikon der Germanischen Altertumskunde (Duczko 1998, 410). It took several decades before some surveys showing the lack of validity in Kumlien's arguments were published. Henrik Janson and Magnus Alkarp have demonstrated the incorrectness of the claim (going back to Eric Benzelius and of crucial importance for Kumlien's hypothesis) that the very existence of bishop Charles had been unknown at the time when Annotationes were published, and confirmed only later (Janson 2001, 48-50; Alkarp 2009, 204-208). The arguments adduced by Schefferus and Annerstedt are enriched by Janson with the words "S.Papae" in the last record. One can only explain them as "Sancti Papae", and such a way to refer to the Pope is unthinkable for a catholic. It can only have been invented by a person who wants to imitate a catholic but is chronologically situated too far from the Swedish Reformation to perceive the impossibility of such a phrase (Janson 2001, $59 \mathrm{n}$. 45). In another recent article, Daniel Sävborg analyses the Icelandisms in the Annotationes (Sävborg 2017, 76-78) and remarks that king Inge elsewhere is called Yggemundus (cf. 
the record under the year 1138) in one single source, namely one of the manuscripts of Hervarar saga - not the best one, but the very manuscript that was used by Verelius when preparing the edition of 1672 (Sävborg 2017, 74-75).

The most relevant research area regarding Annotationes is, in my opinion, the question of the forger's ${ }^{2}$ sources and way of working. Sävborg's article has been a significant contribution in this direction. Still, I suppose that there are more details to discover.

As mentioned above, Schefferus was suspicious about the phrase "opus trium deorum" used to refer to the heathen temple (Schefferus 1678, 23-24):

Deinde quid est opus Deorum? An, quod Dii fecerunt? Ita sane alias Latinis hoc significat. Svetonius in Augusto c. 31. Opera cujusque manentibus titulis, restituit. At Excerptor templum voluit intelligi conditum in ipsorum honorem. Quasi esset idem, dicere templum Deorum, et opus Deorum.

Kumlien rejects this remark as "uncomprehensible" ("obegriplig") and in an astonishingly ignorant way claims that it must be unproblematic to use the word 'opus' here, as it sometimes, according to what he found in a dictionary, means "building" (Kumlien $1967,48)$. Of course, no examples are hereby adduced of 'opus' with a genitive of an animate noun that is not a subjective genitive. I have not managed to find such examples in classical or in later Latin either - so Schefferus seems to be (unsurprisingly) right: the expression is extremely odd. However, the choice of the forger here, unlucky as it is, turns out to be not a random one.

Typically for a forgery, Annotationes are on a phrasal level sewn together from a series of sources that were to some extent relevant for their contents and chronologically close to the pretended date of their composition. We have seen that the forger has used a letter by a real bishop Charles and name forms from Icelandic literature. The ultimate source of knowledge about the heathen temple in Uppsala was Gesta Hammaburgensis ecclesiae pontificum by Adam of Bremen. He was present in the controversy between Schefferus and Verelius all the time, and it is surprising that nobody has so far drawn attention to its textual influence in the Annotationes. ${ }^{3}$

The temple is not simply "opus trium deorum", it is "paganicum" as well. The adjective 'paganicus' is extremely rare compared to its synonyms 'paganus' and 'gentilis', and it is true not least for medieval Latin. One of the few authors who had it, so to say, in his active word-stock, is just Adam of Bremen. He uses 'paganicus' three times, one of them in a context dealing with Swedish conditions. The same author, on a different occasion, writes about a fire of the St. Peter church in Bremen (II. 78):

Is, conflagratione templi audita, mox pedem retorsit, iactisque sequenti aestate fundamentis, ad formam Coloniensis ecclesiae disposuit huius nostrae magnitudinem perducere. Et profecto credimus, si longiorem sibi vitam fato concesserint, omne opus ecclesiae finiturus erat paucis annis.

2 The question who it was remains open. Verelius himself is almost clear from suspicion: even if one does not consider his personal qualities, it is clear that he would have accomplished the forgery in a far more competent way. Alkarp's suggestion is that it was most probably Rudbeck (Alkarp 2009, 222). Nils Rabenius and Carl Lundius, the two Rudbeckianists who are famous for establishing a real "factory of forgeries" later, were still very young in 1678, but are perhaps not to be disregarded either (Alkarp 2009, 197-199).

${ }^{3}$ Remarks about possible substantial influence of Adam are, however, made in an article that does not cast into doubt the authenticity of Annotationes (Bonnier 1991, 90). 
It is here that we, in my opinion, can discern a source for "opus trium deorum". The author of Annotationes has found a similar context (building up a church after a fire; note the expression "iactisque fundamentis" as well, a juncture used twice in the Annotationes) in a work he must have been well acquainted with ${ }^{4}$ and substituted the genitive 'ecclesiae' by the genitive 'trium deorum'. The lack of lexical compatibility was hardly a detail that the forger put attention to.

\section{References}

Alkarp M. Det Gamla Uppsala. Berättelser \& Metamorfoser kring en alldeles särskild plats. Occasional Papers in Archaeology 49; Uppsala, Uppsala universitet, 2009.

Annerstedt C. Schefferus och Verelius. En litterär fäjd i sjuttonde seklet, in: Ur Några Antecknares Samlingar. Gärd af tacksamhet och vänskap till mästaren i svensk bokkunskap G. E. Klemming. Uppsala, Edv. Berling, 1891, 119-150.

Annotationes ex scriptis Karoli Episcopi Arosiensis excerptae. [Upsaliae], [Henricus Curio], 1678.

Bonnier A. C. Gamla Uppsala - Från hednatempel till sockenkyrka, in: O. Ferm (ed.), Kyrka och socken $i$ medeltidens Sverige. Studier till Det medeltida Sverige 5. Stockholm, Riksantikvarieämbetet, 1991, 81-111.

Duczko W. Gamla Uppsala, in: Reallexikon der Germanischen Altertumskunde 1998, 10, 409-418.

Janson H. Äkta förfalskning åter bevismaterial. Annotationes ex scriptis Karoli. Scandia 2001, 67 (1), 41-60.

Kumlien K. Biskop Karl av Västerås och Uppsala ärkesätes flyttning. Historiskt arkiv 14. Stockholm, Kungl. Vitterhets Historie och Antikvitets Akademien, 1967.

Sävborg D. Några anmärkningar om Annotationes ex scriptis Karoli och dess källor. Historisk tidskrift 2017, 137 (1), 64-79.

Schefferus J. (ed., comm.) Incerti scriptoris Sveci qui vixit circa ann. Christi MCCCXLIV.breve chronicon de archiepiscopis et sacerdotibus caeteris ecclesiae Upsaliensis. Upsaliae, Henricus Curio, 1673.

Schefferus J. De excerptis annotationibus ex scriptis Caroli episc. Arosiensis per adversarios expressum judicium. Holmiae, Henricus Keyser, 1678.

Schefferus J. Ioannis Schefferi Argentoratensis vita. Äldre svenska biografier 1. Uppsala 1915.

Received: February 12, 2020 Accepted: April 16, 2020

${ }^{4}$ It can, of course, be argued that the real bishop Charles, who lived in the $13^{\text {th }}$ century, could theoretically - also have read Adam of Bremen, whose work was written in the 1070s. However, it would be far more difficult to explain why he then chose to imitate it as well. 